\title{
PEDAGOGICAL GRAMMAR AS THE FRAMEWORK OF TEFL RESEARCH. \\ PART 10. THE IMPACT OF FORMAL TEACHING ON THE FOREIGN LANGUAGE ACQUISITION
}

\section{Chernovaty L.M., Doctor of Sciences (Kharkiv)}

The relevance of the paper is accounted for by the need of establishing a common framework to integrate the research in teaching foreign languages, specifically in the development of grammar competence, into a single area with uniform approaches, terminology and criteria. Its aim is to look for the ways of promoting the efficiency of grammar subskills development by taking into consideration its key features, specifically, the role of formal teaching in this process. Basing on the analysis of experimental data related to the effect of the monitor on the sequence of the foreign-language grammar structures acquisition, on the one hand, and the rate and quality of the foreign-language acquisition, on the other, it is concluded that their results are conflicting or, at least, incongruent. The author explains it by the fact that most of the experiments were carried out in the countries where it was possible to communicate in the target language outside the classroom. Hence, it is unfeasible to distinguish the improvement of the subjects' performance that resulted from the formal teaching (i.e. "learning", in Krashen's terminology) and the one brought about by communicating in the target language environment outside the class room (i.e. "acquisition"). The author assumes that in the experiments that showed low efficiency of formal teaching as opposed to "acquisition" in the target language environment outside the classroom, the subjects might have practised outside the class room much more than they did in the class room. And the picture might have been the opposite one in the experiments that proved the advantage of the formal teaching. The author believes that the main shortcoming of the said research is the absence of information concerning the subjects' activities outside the classroom. It is important, as some subjects might have intensively communicated with the native speakers outside the classroom improving their command of English, while others, due to the circumstances or personal characteristics (anxiety, etc.) might have been isolated from that kind of communication altogether. This constituted a major random variable that might have affected the experimental results. Furthermore, some subjects might have additionally learned grammar rules in their extracurricular time and thus complemented their "acquisition" mechanisms with those of "learning". The author offers a list of other potential random variables (motivation, anxiety, attitude, aptitude, analytical capabilities, know ledge of the language structure) and outlines the prospects of the further research.

Key words: acquisition, consciousness, foreign language, formal teaching, learning.

(C) Chernovaty L.M., 2021 
Викладання мов у вищих навчальних закладах освіти ...

Черноватий Л.М. Педагогічна граматика як фреймове поняття для досліджень у галузі методики навчання іноземних мов. Частина 10. Вплив формального навчання на засвосння іноземної мови. Актуальність даного дослідження пояснюється необхідністю пошуку шляхів підвищення ефективності процесу формування іншомовних граматичних навичок із урахуванням закономірностей цього процесу, а його метою $\epsilon$ встановлення ролі формального навчання в ньому. Виходячи з аналізу експериментальних даних стосовно впливу монітора на послідовність засвоєння іншомовних граматичних структур, із одного боку, та швидкість і якість засвоєння іноземної мови, 3 іншого, пропонується висновок, що ці результати $\epsilon$ суперечливими чи, принаймні, неоднозначними. Автор пояснює це тим, що більшість із згаданих експериментів проводилися в країнах, де учні могли спілкуватися мовою, яку вони вивчали, за межами класу. Таким чином, неможливо відділити ту частину покращення компетентності випробуваних, яка $\epsilon$ наслідком формального навчання в класі (тобто «учіння», за термінологією С. Крашена) від того, що $є$ наслідком спілкування у мовному середовищі за межами класу (тобто «засвоєння»). Автор припускає, що в експериментах, де виявлено низьку ефективність формального навчання порівняно із «засвоєнням» у мовному середовищі за межами класу, обсяг вправляння випробуваних за межами класу міг значно перевищувати той, який вони мали в класі. А в експериментах, що довели перевагу формального навчання, ситуація могла бути протилежною. Автор уважає головним недоліком проаналізованих експериментів відсутність інформації щодо діяльності випробуваних за межами класу. Така інформація є важливою, оскільки деякі випробувані могли інтенсивно спілкуватися 3 носіями відповідної мови за межами класу, покращуючи своє володіння нею, тоді як інші, в силу обставин або особистісних характеристик (тривожність тощо) могли бути повністю ізольовані від такого спілкування. Це може бути побічною змінною, яка вплинула на результати. Деякі випробувані могли додатково вивчати граматичні правила за межами класу i, таким чином, доповнювати власні механізми «засвоєння» механізмами «учіння». Автор пропонує перелік інших потенційних побічних змінних (мотивація, тривожність, відношення, здібності, аналітичні схильності, знання структури мови) і окреслює перспективи подальшого дослідження.

Ключові слова: засвоєння, іноземна мова, свідомість, учіння, формальне навчання.

Черноватый Л.Н. Педагогическая грамматика как фреймовое понятие для исследований в области методики обучения иностранным языкам. Часть 10. Влияние формального обучения на усвоение иностранного языка. Актуальность данного исследования объясняется необходимостью поиска путей повышения эффективности процесса формирования иноязычных грамматических навыков с учетом закономерностей этого процесса, а его цель - установление роли формального обучения в нем. Исходя из анализа экспериментальных данных относительно влияния монитора на последовательность усвоения 
иноязычных грамматических структур, с одной стороны, а также скорость и качество усвоения иностранного языка, с другой, предлагается вывод о том, что эти результаты имеют противоречивый или, во всяком случае, неоднозначный характер. Автор объясняет это тем, что болышинство упомянутых экспериментов проводились в странах, где учащиеся могли общаться на изучаемом языке вне класса. Таким образом, невозможно отделить приращение компетентности, которое произошло в результате формального обучения (т.е. «научения», по терминологии С. Крашена), от происшедшего в результате общения в языковой среде вне класса (т.е. «усвоения»). Автор предполагает, что в экспериментах, которые показали невысокую эффективность формального обучения по сравнению с усвоением вне класса в языковой среде, испытуемые просто гораздо больше упражнялись вне класса, чем на занятиях. А в экспериментах, которые показали преимущество формального обучения, ситуация могла быть обратной. Автор считает основным недостатком этих исследований отсутствие информации о деятельности испытуемых вне класса. Эта информация важна, т.к. одни испытуемые могли интенсивно общаться с носителями языка, совершенствуя свое владение им, а другие, в силу обстоятельств или личностных характеристик (тревожность и т.п.), могли вообще не вступать в такое общение. Это может быть побочной переменной, которая повлияла на результаты. Кроме того, некоторые испытуемые могли самостоятельно изучать правила грамматики за пределами класса, дополняя собственные механизмы «усвоения» механизмами «научения». Автор предлагает перечень других потенциальных побочных переменных (мотивация, тревожность, отношение, способности, аналитические склонности, знание структуры языка) и очерчивает перспективы дальнейшего исследования.

Ключевые слова: иностранный язык, научение, сознание, усвоение, формальное обучение.

Problem statement. Introduction to the series. Numerous research in teaching foreign languages, specifically in the development of grammar competence, often seem to lack a common framework to integrate them into a single area with uniform approaches, terminology and criteria. It accounts for the current importance of the issue under consideration.

The aim. The object of this part of the series is the comparative aspect of the native (NLA) and foreign languages acquisition (FLA) with the subject being the characteristics of the FLA, specifically the impact of formal teaching on this process. Its aim is to analyse the latter with the purpose of its further accounting for in the development of academic programs and actual teaching. This is the tenth (see the previous issues of this journal starting with $\mathrm{N} 29$ ) in a series of articles 
focusing on the Pedagogical Grammar (PG) issue [1], where the author, basing on the research data, is planning to discuss the various aspects of the problem.

As it was mentioned in the previous papers of the series (see the note above), the development of an effective PG should be based on a sound psycholinguistic theory of the FLA. This kind of PG has to take into consideration the specifics of the speech grammar mechanisms development in general and the foreign language grammar mechanisms in particular, especially in the spheres where the NLA and FLA features are different. In this paper, we are going to review the state of the art in the domain of the impact of formal teaching on the FLA process with a special emphasis on its grammar.

Analys is of current research. The term "formal teaching", in its broad meaning, corresponds to Krashen's term "learning" and is opposed to "acquisition" in the natural environment [15]. Formal teaching may assume various forms (inductive, deductive, interim) depending on the explicitness of the rules used in it, the types of such rules, the intensity of class activities and other factors (see [6: 216217]). The main features of the formal teaching involve the goaldirected, teacher-controlled acquisition of grammar and some kind of the conscious realisation of the target structure by the learner. The latter assumes some form of monitoring. Within the analysed approach, the monitor is defined as part of an individual's speech mechanisms responsible for the foreign language learning, i.e. the one based on consciousness raising [5: 58].

The effect of the formal teaching upon the foreign-language acquisition may be analysed in several aspects. First, it is assumed that the sequence of grammar structures presentation in formal teaching may affect the "natural" (observed in the native language) order of the ir acquisition, i.e. their sequence in formal teaching may determine the said order [6: 216]. Besides, various types of formal teaching (inductive, deductive, etc) may result in the varying degrees of the monitor use. These two aspects of the problem under consideration have been analysed in the experimental research conducted over a considerable period. In general, these experiments may be subdivided into two groups. Within one of them $[6-8 ; 10 ; 21-24 ; 29 ; 31]$, the focus was on the monitor and the sequence of the foreign-language grammar structures acquisition, while the other dealt with the monitor, rate and quality of the foreign-language acquisition [2-4; 11-20;26;27; 32]. 
The experiments produced conflicting, or at least, incongruent results, which are analyzed further.

Presentation of the main material. The monitor and the sequence of the foreign-language grammar structures acquisition. The issue of the natural acquisition sequence has already been analysed in our earlier articles in the series (see Parts 5-7). Here, we review only the research having the direct relation to the issue under discussion. The experiments [8: $21 ; 22 ; 28]$ studied the sequence of the foreign-language grammar structures acquisition in formal teaching. Some subjects in those experiments learned English in the countries (USA or Canada) where it is used as the primary means of communication. That is, it is impossible to make a reliable conclusion whether the obtained data is the result of the formal classroom teaching, informal communication outside the classroom or (which is the most probable variant) - the combined effect of "learning" and "acquisition". The studies involved 475 subjects, from 6 to 22 years of age. Their language command level ranged from elementary to intermediate. The speech elicitation procedures varied from translation from their native language and grammar tests to spontaneous interviews (the latter was an obligatory component in all studies).

The general conclusions in all studies ran as follows. In spontaneous interviews, the sequence of the foreign-language grammar structures acquisition corresponded to their natural order (i.e. sequence observed in the native-language acquisition) and did not correspond to the sequence of their presentation in the formal classroom teaching. On the other hand, in translation and grammar tests, the sequence of the grammar structures acquisition corresponded to the sequence of their presentation in the formal teaching. Some researchers [6] explain it by the fact that in the tasks allowing enough time for conscious control (i.e. the monitor use, in Krashen's terminology), the learners apply it to edit their speech. It considerably (up to $40 \%$ in some studies [31]) improves the quality of their speech. These experimental results may be interpreted in favour of both the "acquisition vs learning" and "monitor" hypotheses.

The interpretation of this data, however, is complicated by the fact of the subjects' learning in the countries where the target language is used as the means of communication. Thus, we cannot avoid the dependent variable (the sequence of the foreign-language grammar structures acquisition) being affected by random variables, the principal one being 
the acquisition of the said structures as the result of the subjects' communication with the native speakers outside the classroom. More rigorous, in the light of their effect on the sequence of acquisition, are the experiments where the subjects learned a foreign language only in the classroom, and did not have any chance to get into the target language environment outside the classroom. The reviews of this problem [6] provide the data on the acquisition sequence of over 800 subjects in Germany, Japan, Finland and Mexico whose learning of a foreign language was limited to the classroom. Three experiments' data [7: 24; 29] relied on the subjects' spontaneous speech testing only and one study [9] involved an 8-week (40 hours) experimental teaching of subjects 10 to 50 years of age. The speech elicitation procedure in all experiments were close to spontaneous communication (recording of free interviews, communication among subjects, etc.). In one case [24], the subjects also answered questions in writing, in three others [7:24; 29 ] - the subjects' levels of language command were different, while in one study [10] - all subjects were beginners.

The conclusions in all experiments were quite similar - there were no distinctions in the classroom acquis ition sequence as compared to the one registered in the native language. In the experiment where the actual teaching was involved [10], it was concluded that the process of classroom language acquisition and the one related to the natural environment are basically identical. According to the author, when a problem arises, the learners may resort to two strategies - either rely on the natural mechanisms (in this case, the structures observed in the ir speech are identical to those used in the natural environment acquisition) or choose the structures at random (in which case it is impossible to discover any pattern in this process).

The latter study [10] is of a special interest as it is based on a relatively lengthy experimental teaching. For the sake of comparison, it seems appropriate to have a look at two more studies based on a similar approach [6: 31]. There were three younger (10 to 13 years old) and one adult subjects who learned English in the USA and UK correspondingly, i.e. both in the classroom and outs ide it. The course lasted nine months in the first study [6] and seven months in the second one [284]. The subjects' speech was recorded throughout the entire course of study. In both experiments, the subjects were beginners and the samples of their speech were spontaneous. In the second experiment [31], the specific structures elicitation procedure was also used. The 
results demonstrated a considerable improvement (64\% against $22 \%$ before the experiment) of the subject's general speech accuracy but little improvement in the use of some structures specifically taught within this particular course. In both experiments, the sequence of the structures acquisition corresponded to the natural one.

The monitor, rate and quality of the foreign-language acquisition. There are some general assumptions concerning the impact of monitoring upon the rate of acquisition. According to them, the monitor accelerates this process at the initial stage but eventually the nonmonitor learners (especially children, and especially younger ones) perform better using the "acquisition" route. These assumptions should be probably taken with a pinch of salt because of the fuzzy terms used by the ir authors. First, it is not quite clear what "eventually" means here (a year? three? five?). Second, while describing the "monitor" Krashen himself admits that monitoring may be carried out not only through the conscious control of one's own speech but through the "feel of grammaticality" as well [15: 2]. This remark brings a considerable confusion into the monitor theory itself as it becomes practically impossible to identify the monitoring mode (conscious control or the "feel of grammaticality") in each specific instant. In any case, we have to admit the lack of sufficient data regarding the assumed impact of the formal teaching on the rate of a foreign language acquisition.

As far as the quality of acquisition is concerned, the situation is somewhat different. There have been a considerable amount of research (of varying quality) regarding this issue. The said studies produced conflicting data. Considering their results, the experiments may be subdivided into three groups. Within the first group of studies [4; 17; 18], their authors arrived at the conclusion that formal teaching contributes to the efficient acquisition of a foreign language, while the mere staying in the language environment - does not. All experiments studied adult subjects with different native languages. In two studies [17; 18], English was learned in the country where it is used as the means of communication (USA), and in one case [4], the language environment outside the classroom was absent (Japan). As regards their command of English, the subjects were characterized as a mixed group. To elicitate the subjects' speech samples, two types of tests were used: multiple choice [18], Cloze-test [17] or both [4].

The findings in this group of research were corroborated by the later data obtained in the study of the comparative efficiency of implic it and 
explic it instruction $[11 ; 12 ; 20 ; 23 ; 25 ; 32]$. For example, the enquiry in advanced adult classes [12] disclosed that explicit instruction resulted in more uptake as compared to the implicit one. Likewise, another investigation [25] revealed that acquis ition efficiency can be improved by highlighting the relationship between grammatical forms and their meanings [25: 147], while the survey of the learners' attitude to learning grammar [11] showed the students' positive view as to explicit teaching.

Within the second group of studies $[2 ; 3 ; 15 ; 16]$, the researchers concluded that both the formal teaching and staying in the language environment have a positive effect upon the foreign language acquisition. In all these experiments, learning took place in the country where the target language was used as the means of communication (English in the USA - three studies, and Spanish in Mexico - one). In the latter case, the subjects were children whose native language was the one of a local Indian tribe. In the remaining experiments, the participants were adults with various native languages and varying degrees of their command of English. In one study [2], all subjects were beginners. In two experiments $[15 ; 16]$, both discrete and integrative tests were applied, while the other two used only discrete [2] or only integrative [3] ones. The analysis of the results of over 180 subjects proved that there is a considerably better correlation of the learning efficiency with the total amount of time of formal teaching than with that of staying in the target language environment.

Within the third group of studies $[6 ; 8 ; 9 ; 13 ; 26 ; 32]$, the authors inferred that formal teaching does not have any positive impact upon the foreign language learning. Moreover, in one of the experiments [13], it was assumed that the impact of formal teaching might actually be negative. The said results were obtained following the analys is of the utterances produces by the subjects with various native languages. All experiments were conducted in the countries (USA and UK) where the target language was used as the means of communication. The subjects were children [6; 8; 9], teenagers [13] and adults [26; 32]. Five experiments applied discrete [32], integrative [9] tests or the combination of the two. In one study [6], the elicitation of the subjects' spontaneous speech was done by showing pictures to them.

Later studies $[14 ; 19 ; 27]$ were more restrained about the advantages of implicit approaches, but nevertheless established that implicitly taught learners outperformed the implicitly taught ones in the quality of 
acquisition, retention and understanding of the material [27] or, at least, that the combined effect of explicit and implicit teaching was not superior to the implicit one alone [14].

Conclusions. Thus, the three groups of researchers, independently conducting their experiments within different periods and applying generally similar experimental schemes, obtained conflicting (or, at least, incongruent) results. The main reason for it might be the fact that most of the experiments were carried out in the countries where it was possible to communicate in the target language outside the classroom. Hence, it is unfeasible to distinguish the improvement of the subjects' performance that resulted from the formal teaching (i.e. the use of "learning"'and, presumably, "monitoring") and the one brought about by staying (and communicating) in the target language environment outside the classroom (i.e. the use of "acquisition"). Purely theoretically, it may be assumed that in the experiments that showed uselessness or low efficiency of formal teaching as opposed to "acquisition" in the target language environment outside the classroom, the subjects merely practised outside the classroom much more than they did in the classroom. And the picture might have been the opposite one in the experiments that proved the advantage of the formal teaching. The main shortcoming of the said research is the lack of information concerning the subjects' activities outside the classroom. It is vitally important as some subjects might have intensively communicated with the native speakers outside the classroom improving the ir command of English, while others, due to the circumstances or personal characteristics (high level of anxiety, etc.) might have been isolated from that kind of communication altogether.

It seems quite evident that though the subjects were in the same class, their results, in spite of being exposed to the same teaching in the classroom, could have been substantially dissimilar. The different intensity of the their communication outside the classroom is the random variable that might have affected the dependent variable (efficiency of the foreign language acquisition). In this case, the results of the said experiments cannot be regarded as reliable. The ambiguity concerning the subjects' activities outside the classroom makes it difficult to analyse the role of the conscious factor (the "monitor") in the foreign language acquisition as well. Some subjects might have used part of their extracurricular time to learn grammar rules having complemented the mechanisms of "acquisition" in the target language 
environment with the corresponding mechanisms of "learning". However, in the experiments under consideration, this random variable had not been controlled either. There are some other random variables that had not been taken into account in the said experiments, such as the subjects' motivation, their level of anxiety, attitude to the target language and learning, their aptitude, analytical capabilities, the knowledge of the language structure (both of the native and the target ones), etc. All those and other variables might have potentially affected the experimental results.

Hence, the comparative analysis of the problem under consideration constitutes the prospect of our further research.

\section{LITERATURE}

1. Черноватый Л.Н. Основы теории педагогической грамматики иностранного языка: дис. ... д-ра пед. наук: 13.00 .02 / Харьковский нац. ун-т им. В.Н.Каразина. Харьков, 1999. 453 с.

2. Briere E. Variables affecting native Mexican children's learning Spanish as a second language. Language Learning. 1978. Vol. 28. N 1. P. 159-174.

3. Carroll J. Foreign language proficiency levels trained by language majors near graduation from college. Foreign Language Annals. 967. Vol. 1. N 2. P. 131-151.

4. Chihara T., Oller J. Attitudes and attained proficiency in EFL: a sociolinguistic study of adult Japanese speakers. Language Learning. 1978. Vol. 28. N 1. P. 55-68.

5. Dulay H., Burt M., Krashen S. Language Two. New York: Oxford Univ. Press, 1982. 315 p.

6. Ellis R. Understanding Second Language Acquisition. London: Oxford Univ. Press, 1989. 327 p.

7. Fathman A. ESL and EFL learn ing: similar or dissimilar? C. Blatchford and J. Schachter (eds.). On TESOL'78: EFL Policies, Programs, Practices. Washington, D.C.: TESOL. 1978. P 48-56.

8. Fathman A. Language background, age and the order of acquisition of English structures. M. Burt and H. Dulay (eds.). New Direction in Second Language Learning, Teaching and Bilingual Education. Washington, D.C.: TESOL, 1975. P. 33-43.

9. Fathman A. Variables affecting the successful learning of English as a second language. TESOL Quarterly. 1976. Vol. 10. N 4. P. 433-441.

10. Felix S. The effect of formal instruction on second language acquisition. Language Learning. 1981. Vol. 31. N 1. P. 87-112. 
11. Fujino H. L2 learners' perceptions of grammar: the case of JFL learners in the UK. The Language Learning Journal. 2019. DOI: 10.1080/09571736.2019.1578399. Published Online: 01 Mar 2019.

12. Gholami L., Gholami J. Uptake in incidental focus-on-form episodes concerning formulaic language in advanced adult EFL classes. Language Teaching Research. 2020. Vol. 24, N 2. P. 189-219. DOI: https://doi.org/10.1177/1362168818783442.

13. Hale T., Budar E. Are TESOL classes the only answer? Modern Language Journal. 1970. Vol. 4. N 7. P. 487-492.

14. Hernández T.A. Re-examining the role of explicit instruction and input flood on the acquisition of Spanish discourse markers. Language Teaching Research. 2011. Vol. 15. N 2. P. 159-182. DOI: https://doi.org/10.1177/1362168810388694.

15. Krashen S. Second Language Acquisition and Second Language Learning. Cambridge: Prentice Hall, 1981. 212 p.

16. Krashen S., Jones C., Zelinaky S., Usprich C. How important is instruction? ELT Journal. 1978. N. 32. P. 257-261.

17. Krashen S., Seliger H. The role of formal and informal linguistic environments in adult second language learning. International Journal of Psycholinguistics. 1976. N 3. P. 15-21.

18. Krashen S., Seliger H., Hartnett, D. Two studies in second language learning. Kritikon Literarum. 1974. Vol. 2. N 3. P. 220-228.

19. Leow R.P. ISLA: How implicit or how explicit should it be? Theoretical, empirical, and pedagogical/curricular issues. Language Teaching Research. 2018. Vol. 23. N 4. P. 476-493. DOI: https://doi.org/ $10.1177 / 1362168818776674$.

20. Liamkina O., Ryshina-Pankova M. Grammar Dilemma: Teaching Grammar as a Resource for Making Meaning. The Modern Language Journal. 2012. Vol. 96. N 2. P. 270-289. DOI: https://doi.org/10.1111/j.1540781.2012.01333_1.x.

21. Lightbown P. Exploring relationships between developmental and instructional sequences in L2 acquisition. Seliger M., Long M. (Eds.). Classroom Oriented Research in Second Language Acquisition. Rowley, Mass.: Newbury House. 1983. P. 82-91.

22. Lightbown P., Spada N., Wallace R. Some effects of instruction on child and adolescent ESL learners. Scarcella, R. and S.Krashen (Eds.). Research in Second Language Acquisition. Rowley, Mass.: Newbury House. 1980. P. 68-81.

23. Liviero S. Grammar teaching in secondary school foreign language learning in England: teachers' reported beliefs and observed practices, The Language Learning Journal.2017. Vol.45 (1), pp. 26-50. DOI: $10.1080 / 09571736.2016 .1263677$. 
24. Makino T. English morpheme acquisition order of Japanese secondary school students. Abstract of PhD Dissertation. TESOL Quarterly. 1979. N 13. P. 428.

25. Marsden H., Slabakova R. Grammatical meaning and the second language classroom: Introduction. Language Teaching Research. 2017. Vol. 23. N 2. P. 147-157. DOI: https://doi.org/10.1177/1362168817752718.

26. Mason C. The relevance of intensive training in English as a foreign language for university students. Language Learning. 1971. Vol. 21. N 2. P. 197-204.

27. Mei-Hsing Tsai. The effects of explicit instruction on L2 learners' acquisition of verb-noun collocations. Language Teaching Research. 2018.
Vol. 24.
$\mathrm{N} 2$.
P. $138-146$.
DOI: https://doi.org/10.1177/1362168818795188.

28. Perkins K., Larsen-Freeman D. The effect of formal language instruction on the order of morpheme acquisition. Language Learning. 1975. Vol. 25. N 2. P. 237-243.

29. Pica T. Adult acquisition of Eng lish as a second lang uage under different conditions of exposure. Language Learning. 1983. Vol.33. N 4. P. 465-497.

30. Schumann J. The Pidginization Process: A Model for Second Language Acquisition. Rowley, Mass.: Newbury Press, 1978. 276 p.

31. Umeda M., Snape N., Yusa N., W iltshier J. The long-term effect of explic it instruction on learners' knowledge on English articles. Language Teaching Research. $\quad 2017 . \quad$ Vol. $23 . \quad$ N 2. P. 79-199. DOI: https://doi.org/10.1177/1362168817739648

32. Upshur J. Four experiments on the relation between foreign language teaching and learning. Language Learning. 1968. Vol. 18. NN 1-2. P. 111-124.

\section{REFERENCES}

1. Chernovaty, L. (1999). Osnovy teorii pedagogicheskoi grammatiki inostrannogo yazyka [The Basics of the Foreign Language Pedagogical Grammar Theory]. Doctor of Sciences thesis. Kharkiv: V.N.Karazin Kharkiv National University [in Russian].

2. Briere, E. (1978). Variables affecting native Mexican children's learning Spanish as a second language. Language Learning, vol. 28(1), pp. 159-174 [in English].

3. Carroll, J. (1967).Foreign language proficiency levels trained by language majors near graduation from college. Foreign Language Annals, vol. 1(2), pp. 131-151 [in English]. 
4. Chihara, T. and Oller, J. (1978). Attitudes and attained proficiency in EFL: a sociolinguistic study of adult Japanese speakers. Language Learning, vol. 28(1), pp. 55-68 [in English].

5. Dulay, H., Burt, M. and Krashen, S. (1982). Language Two. New York: Oxford Univ. Press [in English].

6. Ellis, R. (1989). Understanding Second Language Acquisition. London: Oxford Univ. Press [in English].

7. Fathman, A. (1978). ESL and EFL learning: similar or dissimilar? In: C. Blatchford and J. Schachter (Eds.). On TESOL'78: EFL Policies, Programs, Practices. Washington, D.C.: TESOL, pp. 48-56.

8. Fathman, A. (1975). Language background, age and the order of acquisition of English structures. In: M. Burt, H. Dulay (Eds.). New Direction in Second Language Learning, Teaching and Bilingual Education. Washington, D.C.: TESOL, pp. 33-43 [in English].

9. Fathman, A. (1976). Variables affecting the successful learning of English as a second language. TESOL Quarterly, vol.10(4), pp.433-441 [in English].

10. Felix, S. (1981). The effect of formal instruction on second language acquisition. Language Learning, vol. 31(1), pp. 87-112 [in English].

11. Fujino, H. (2019). L2 learners' perceptions of grammar: the case of JFL learners in the UK. The Language Learning Journal [in English]. DOI: 10.1080/09571736.2019.1578399. Published Online: 01 Mar 2019.

12. Gholami, L. and Gholami, J. (2020). Uptake in incidental focus-on-form episodes concerning formulaic language in advanced adult EFL classes. Language Teaching Research, vol. 24 (2), pp. 189-219 [in English]. DOI: https:/doi.org/10.1177/1362168818783442.

13. Hale T. and Budar E. (1970). Are TESOL classes the only answer? Modern Language Journal, vol. 54(7), pp. 487-492 [in English].

14. Hernández, T.A. (2011). Re-examining the role of explicit instruction and input flood on the acquisition of Spanish discourse markers. Language Teaching Research, vol.15(2), pp.159-182 [in English]. DOI: https://doi.org/10.1177/1362168810388694.

15. Krashen, S. (1981). Second Language Acquisition and Second Language Learning. Cambridge: Prentice Hall [in English].

16. Krashen, S., Jones, C., Zelinaky, S., Usprich, C. (1978). How important is instruction? ELT Journal, N. 32, pp. 257-261 [in English].

17. Krashen, S. and Seliger, H. (1976). The role of formal and informal linguistic environments in adult second language learning. International Journal of Psycholinguistics, N3, pp. 15-21 [in English].

18. Krashen, S., Seliger, H.and Hartnett, D. (1974). Two studies in second language learning. Kritikon Literarum, vol. 2(3), pp. 220-228 [in English].

19. Leow, R.P. (2018). ISLA: How implicit or how explicit should it be? Theoretical, empirical, and pedagogical/curricular issues. Language 
Teaching Research, vol.23, N 4. P. 476-493 [in English]. DOI: https://doi.org/10.1177/1362168818776674.

20. Liamkina, O. and Ryshina-Pankova, M. (2012). Grammar Dilemma: Teaching Grammar as a Resource for Making Meaning. The Modern Language Journal, vol.96(2), pp.270-289 [in English]. DOI: https://doi.org/10.1111/j.1540-781.2012.01333_1.x.

21. Lightbown, P. (1983). Exp loring relationships between developmental and instructional sequences in L2 acquisition. In: Seliger M., Long M. (eds.). Classroom Oriented Research in Second Language Acquisition. Rowley, Mass.: Newbury House,pp. 82-91 [in English].

22. Lightbown, P., Spada, N. and Wallace, R. (1980). Some effects of instruction on child and adolescent ESL learners. In: Scarcella, R. and S. Krashen (Eds.). Research in Second Language Acquisition . Rowley, Mass.: Newbury House, pp. 68-81 [in English].

23. Liviero, S. (2017). Grammar teaching in secondary school foreign language learning in England: teachers' reported beliefs and observed practices. The Language Learning Journal, vol.45(1), pp.26-50 [in English]. DOI: $10.1080 / 09571736.2016 .1263677$.

24. Makino, T. (1979). English morpheme acquisition order of Japanese secondary school students. Abstract of PhD Dissertation. TESOL Quarterly, $N$ 13, p. 428 [in English].

25. Marsden, H. and Slabakova, R. (2017). Grammatical meaning and the second language classroom: Introduction. Language Teaching Research, vol.23(2), pp. 147-157 [in English]. DOI: https://doi.org/ $10.1177 / 1362168817752718$.

26. Mason, C. (1971). The relevance of intensive training in English as a foreign language for university students. Language Learning, vol. 21(2), pp. 197-204 [in English].

27. Mei-Hsing, T. (2018). The effects of explicit instruction on L2 learners' acquisition of verb-noun collocations. Language Teaching Research, vol. 24(2), pp. 138-146 [in English]. https://doi.org/10.1177/1362168818795188.

28. Perkins, K. and Larsen-Freeman, D. (1975). The effect of formal language instruction on the order of morpheme acquisition. Language Learning, vol. 25(2), pp. 237-243 [in English].

29. Pica, T. (1983). Adult acquisition of English as a second language under different conditions of exposure. Language Learning, vol. 33(4), pp. 465497 [in English].

30. Schumann, J. (1978). The Pidginization Process: A Model for Second Language Acquisition. Rowley, Mass.: Newbury Press [in English].

31. Umeda, M., Snape, N., Yusa, N. and Wiltshier, J. (2017). The long-term effect of explicit instruction on learners' knowledge on English articles. 
Language Teaching Research, vol.23(2), pp. 179-199 [in English]. DOI: https://doi.org/10.1177/1362168817739648

32. Upshur, J. (1968). Four experiments on the relation between foreign language teaching and learning. Language Learning, vol. 18, NN 1-2, pp. 111-124.

Черноватий Леонід Миколайович, докт. пед. наук, професор кафедри перекладознавства імені Миколи Лукаша факультету іноземних мов Харківського національного університету імені В.Н. Каразіна (61022, Харків, майдан Свободи, 4); e-mail: leonid.chernovaty @karazin.ua; orcid: http://orcid.org/0000-0003-3411-9408.

Черноватый Леонид Николаев ич, докт. пед. наук, профессор кафедры переводоведения имени Николая Лукаша факультета иностранных языков Харьковского национального университета имени В.Н. Каразина (61022, Харьков, площадь Свободы, 4); e-mail: leonid.chernovaty@karazin.ua; orcid: http://orcid.org/0000-0003-3411-9408.

Leonid Chernovaty, Doctor of Pedagogics, Full Professor, The School of Foreign Languages, Mykola Lukash Translation Studies Department, V.N. Karazin Kharkiv National University (61022, Kharkiv, 4 Svoboda Square); e-mail: leonid.chernovaty@karazin.ua; orcid: http://orcid.org/00000003-3411-9408. 